\title{
SOSIAL DAN KEPRIBADIAN TERHADAP KEPUTUSAN MAHASISWA PEMILIHAN PROGRAM STUDI MANAJEMEN
}

\author{
Sandra Oktaviana Pinaraswati \\ Universitas Dr. Soetomo Surabaya
}

\begin{abstract}
The purpose of this study is to examine and analyze: The influence of social and personality factors on students' decisions in choosing a Management study program. The research method used is explanatory research that is research that explains the causality relationship between several variables through hypothesis testing. Data collection techniques using a questionnaire or questionnaire in the form of a Likert scale. The research respondents were undergraduate students of 2017 management study program at Higher Education in Surabaya with a total sample of 281 students. The analytical model in this study is to use multiple linear regression analysis. The results showed the R Square coefficient of 0.504 means that the Student Decision variable can be explained by Social and Personality variables, by $50.4 \%$. While the remaining $49.6 \%$ can be explained by other variables not examined by this study. Simultaneous testing shows that the independent variables namely Social and Personality together affect the Student's Decision. This is indicated by the $\mathrm{F}$ count of 141,161 . The partial test of research variables shows that the independent variables, namely Social and Personality, influence the dependent variable, namely Student Decisions.
\end{abstract}

Keywords : Social, Personality, Student Decisionss

Correspondence to : Sandra.oktaviana@unitomo.ac.id

\section{PENDAHULUAN}

PTS di kota Surabaya dan banyaknya jumlah program studi menyebabkan persaing-an antar PTS dan antar prodi yang semakin ketat. PTS di Kota Surabaya bersaing untuk menarik minat mahasiswa yang akan melanjutkan studinya ke perguruan tinggi. Agar memenangkan persaingan, masing-masing prodi di PTS giat berusaha meningkatkan kualitas dan kuantitasnya, mulai dari merekrut dosen, bekerja sama dengan PTN dan PTS dalam dan luar negeri, melengkapi fasilitas maupun giat melakukan promosi di berbagai media. Disisi lain persaingan tersebut secara tidak langsung memberi keuntungan tersendiri bagi mahasiwa, karena mahasiswa mempunyai banyak pilihan untuk memutuskan program studi dan perguruan tinggi mana yang akan dipilih. Mahasiswa yang rasional tentunya akan memilih program studi dan PTS yang bermutu.

Mengantisipasi fakta tersebut maka proses pengambilan keputusan mahasiswa dalam memilih program studi di PTS tertentu sangat penting untuk diketahui oleh para pengelola perguruan tinggi swasta melalui kajian perilaku konsumen. Kotler dan Keller (2012:173) mengemukakan bahwa perilaku konsumen adalah studi tentang bagaimana individu, kelompok, dan organisasi memilih, membeli, menggunakan, dan bagaimana barang, jasa ide, atau pengalaman untuk memuaskan kebutuhan 
dan keinginan mereka, dalam melakukan pembelian, perilaku konsumen dipengaruhi beberapa faktor diantaranya faktor budaya, sosial, kepribadian dan psikologis. Pemasar harus berusaha untuk memahami konsumen,mengetahui apa yang dibutuhkannya, apa seleranya dan bagaimana ia mengambil keputusan. Setiadi (2003:11) keputusan pembelian sangat dipengaruhi oleh 4 faktor, yaitu : 1). Kebudayaan yang meliputi : budaya, sub budaya, dan kelas sosial. 2). Sosial, meliputi Kelompok referensi, keluarga, peran dan status. 3). Kepribadian, meliputi : Umur dan tahapan dalam siklus hidup, pekerjaan, keadaan ekonomi, gaya hidup, kepribadian dan konsep diri. 4). Psikologis, meliputi : motivasi, persepsi, proses belajar, kepercayaan dan sikap. Faktor-faktor yang dapat mempengaruhi keputusan pembelian, peneliti hanya fokus pada faktor sosial dan kepribadian dengan alasan adanya kontroversi dalam hasil penelitian sebelumnya.

Faktor sosial meliputi tiga (3) lingkup yaitu kelompok acuan, keluarga, dan peran status(Kotler dan Keller,2017:217). Kelompok acuan terdiri dari seluruh kelompok yang mempunyai pengaruh langsung maupun tidak langsung terhadap sikap ataupun perilaku seseorang. Pengaruh kelompok cukup kuat atas produk yang dianggap baik oleh orang orang yang dihormati pembeli. Hampir setiap orang secara tetap melakukan interaksi dengan orang lain yang secara langsung mempengaruhi keputusan pembelian mereka. Studi mengenai kelompok dan dampaknya terhadap individu sangat penting bagi pemasar yang berkepentingan untuk mempengaruhi perilaku para konsumen. Dalam mengambil suatu keputusan, kebanyakan konsumen menganggap bahwa keluarga merupakan kelompok referensi yang utama dalam berbagai sikap dan perilaku. Keluarga didefinisikan sebagai dua orang atau lebih yang dihubungkan oleh darah, pernikahan, atau adopsi yang tinggal bersama-sama. Seseorang pada umumnya berpartisipasi dalam kelompok selama hidupnya misalnya dalam keluarga, organisasi dan klub. Posisi seseorang dalam setiap kelompok dapat didefinisikan dalam peran dan status. Penelitian Mariaji dan Yuniati (2014), Haqueet al. (2010), bahwa faktor sosial berpengaruh signifikan terhadap keputusan konsumen. Sedangkan penelitian Darmawati et al. (2007), Sitohang (2013), Iskandar (2015), Setiawanta dan Tristiarini (2013) mengungkapkan bahwa faktor sosial berpengaruh tidak signifikan terhadap keputusan konsumen.

Keputusan pembelian juga dipengaruhi oleh karakteristik pribadi. Karakteristik pribadimeliputi usia dan tahapan dalam siklus hidup, pekerjaan, keadaan ekonomi, kepribadian dan konsep diri, serta nilai dan gaya hiduppembeli. Penelitian Darmawati et al. (2007), Mariaji dan Yuniati (2014), Iskandar (2015), mengungkapkan bahwa faktor pribadi berpengaruh signifikan terhadap keputusan konsumen. Sedangkan penelitian, Nouraieet al. (2014), Sitohang (2013), mengungkapkan bahwa faktor pribadi berpengaruh tidak signifikan terhadap keputusan konsumen.

Program studi Manajemen mempunyai peminat yang lebih banyak dibanding dengan prodi lain, sehingga persaingan untuk bisa diterima di prodi manajemen sangatlah ketat. Faktor-faktor yang mempengaruhi mahasiswa dalam memilih program studi manajemen dan perguruan tinggi yang menyelenggarakan program studi manajemen sangat penting untuk diketahui oleh para pengelola perguruan tinggi guna menentukan 
strategi apa yang harus dilakukan oleh perguruan tinggi untuk bisa menarik calon mahasiswa.sehingga peneliti tertarik untuk meneliti faktor-faktor yang mempengaruhi mahasiswa untuk memilih program studi manajemen.

Berdasarkan latar belakang tersebut, maka rumusan masalah dalam penelitian ini, adalah: (1) Apakah Sosial dan Kepribadian berpengaruh secara simultan terhadap keputusan mahasiswa memilih program studi Manajemen pada Perguruan Tinggi Swasta di Surabaya? (2) Apakah Sosial berpengaruh secara parsial terhadap keputusan mahasiswa memilih program studi Manajemen pada Perguruan Tinggi Swasta di Surabaya?3 .Apakah kepribadian berpengaruh secara parsial terhadap keputusan mahasiswa memilih program studi Manajemen pada Perguruan Tinggi Swasta di Surabaya?

Studi tentang perilaku konsumen merupakan hal penting dalam manajemen pemasaran. Para pemasar wajib memahami perilaku konsumen agar mereka mampu memasarkan produknya dengan baik, dapat merancang strategi pemasaran yang sesuai, dan dapat memiliki kemampuan bersaing yang lebih baik.Engel et al., (2006) dalam (Sangadji, 2013: 7) perilaku konsumen adalah tindakan yang langsung terlibat dalam pemerolehan, pengonsumsian, dan penghabis-an produk/jasa, termasuk proses yang mendahului dan menyusul tindakan ini. Sedangkan menurut Sumarwan (2003:26) perilaku konsumen adalah semua kegiatan, tindakan, serta proses psikologis yang mendorong tindakan tersebut pada saat sebelum membeli, ketika membeli, menggunakan, menghabiskan produk dan jasa setelah melakukan kegiatan mengevaluasi.

\section{Sosial}

Lamb (2001) dalam Koesoemaningsih (2013) faktor sosial merupakan sekelompok orang yang sama-sama mempertimbangkan secara dekat persamaan di dalam status atau penghargaan komunitas yang secara terusmenerus bersosialisasi diantara mereka sendiri baik secara formal dan informal. Menurut Setiadi (2003:12) perilaku seorang konsumen juga dipengaruhi oleh faktorfaktor sosial seperti : kelompok referensi, keluarga, serta peran dan status konsumen, faktor-faktor ini berpengaruh pada tanggapan konsumen. (a) Kelompok acuan adalah semua kelompok yang memiliki pengaruh langsung atau tidak langsung terhadap sikap atau perilaku seseorang. Kelompok yang memiliki pengaruh langsung terhadap seseorang dinamakan kelompok keanggotaan. Beberapa kelompok keanggotaan adalah kelompok primer, seperti keluarga, teman, tetangga dan rekan kerja, yang berinteraksi dengan seseorang secara terus menerus dan informal. Orang juga menjadi anggota kelompok sekunder, seperti kelompok keagamaan, profesional dan asosiasi perdagangan yang cenderung lebih formal dan membutuhkan interaksi yang tidak begitu rutin. (b) Keluarga merupakan organisasi pembelian konsumen yang paling penting dalam masyarakat, dan ia telah menjadi obyek penelitian yang luas. Anggota keluarga merupakan kelompok acuan primer yang paling berpengaruh. Kita dapat membedakan antara dua keluarga dalam kehidupan pembeli. Anggota keluarga merupakan kelompok acuan primer yang paling berpengaruh. (c) Peran dan Status. Posisi seseorang dalam suatu kelompok dapat ditentukan dari segi peran dan status. Tiap peran membawa status yang mencerminkan penghargaan umum oleh masyarakat.

\section{Kepribadian}




\section{Suryani (2013:47), kepribadian} dipandang sebagai karakteristik yang ada dalam diri individu yang melibatkan berbagai proses psikologis, yang akan menentukan kecenderungan dan respon seseorang terhadap lingkungan.Kepribadian konsisten dan bertahan dalam waktu yang lama. Hal ini sangat penting bagi pemasar menjelaskan dan meramalkan adanya perilaku konsumen dipandang dari kepribadiannya.

Kotler (2017) keputusan konsumen dipengaruhi olehkarakteristik pribadi. Karakteristik meliputi: usia dan tahap siklus hidup, pekerjaan, keadaan ekonomi, gaya hidup, serta kepribadian dan konsep diri pembeli. (1). Usia dan Tahap Siklus Hidup. Setiap orang membeli barang dan jasa yang berbeda-beda sepanjang hidupnya. Mereka makan makanan bayi pada masa awal hidupnya, makan berbagai makanan selama masa pertumbuhan menuju kedewasaan, serta diet khusus dalam waktu-waktu tertentu. Selera terhadap pakaian, hiburan, dan barang-barang lain juga berhubungan dengan usia. (2)Pekerjaan dan Lingkungan Ekonomi .Pekerjaan dan keadaan ekonomi seseorang mempengaruhi pola konsumsinya. Yang dimaksud dengan keadaan ekonomi seseorang adalah terdiri dari pendapatan yang dapat dibelanjakan (tingkatnya, stabilitasnya, dan polanya), tabungan dan hartanya. (3)Gaya Hidup Orang-orang yang berasal dari sub-budaya, kelas sosial, dan pekerjaan yang sama dapat memiliki gaya hidup yang berbeda. Gaya hidup adalah pola hidup seseorang di dunia yang terungkap pada aktivitas, minat, dan opininya. Gaya hidup menggambarkan keseluruhan diri seseorang yang berinteraksi dengan lingkungannya. (4) Kepribadian dan Konsep Diri. Masingmasing orang memiliki kepribadian yang berbeda mempengaruhi perilaku pembelian. Kepribadian adalah ciri bawaan psikologimanusia yang terberbedakan menghasilkan tanggapan yang relatif konsisten dan bertahan lama terhadap rangsangan lingkungannya.

Menurut Sumarwan (2004 : 49), ada tiga teori kepribadian yang utama yaitu :1) Teori Freud.Teori ini dibangun atas dasar pemikiran bahwa kebutuhan atau dorongan yang tidak disadari, terutama dorongan seksual dan dorongan biologis lainnya, merupakan inti dari motivasi dan kepribadian manusia. Didasarkan kepada analisisnya, Freud mengemukakan bahwa kepribadian manusia terdiri dari 3 sistem yang saling mempengaruhi yaitu $i d$, superego, dan ego. Id dirumuskan sebagai "gudang" dari berbagai dorongan primitif dan impulsif berupa kebutuhan fisiologis dasar sepertirasa haus, lapar, dan seks yang diusahakan individu untuk segera dipenuhi, terlepas dari bagaimana cara yang digunakan untuk memenuhi kebutuhan itu, sedangkan superego dirumuskan sebagai pernyataan diri individu mengenai moral dan kode etik yang berlaku di dalam masyarakat. Peran superego adalah menjaga agar individutersebut memuaskan kebutuhan dengan cara yang dapat diterima masyarakat. Terakhir, yaitu ego, merupakan pengendalian individu secara sadar. Fungsinya sebagai pemantau dalam diri manusia yang berusaha menyeimbangkan tuntutan yang impulsif dengan kendala sosial budaya atas superego. Freud juga menekankan bahwa kepribadian individu dibentuk ketika ia melalui beberapa tahap khas perkembangan bayi dan masa kanakkanak. Tahap-tahap initerdiri dari tahap oral, anal, phallic, laten, dan genital. Menurut teori Freud,kepribadian orang dewasa ditentukan oleh seberapa baik dia menghadapi krisis yang dialami selama melalui setiap tahap ini.Para peneliti yang menerapkan teori psikionalitis Freud pada 
studi kepribadian konsumen percaya bahwa dorongan pada manusia sebagian besar tidak disadari dan bahwa para konsumen terutama tidak menyadari alasan mereka yang sebenarnyaatas pembelian suatu jenis barang/jasa tertentu. Para peneliti ini cenderungmemandang bahwa pembelian konsumen dan kepemilikan barang oleh konsumen sebagai cerminan dari kepribadian individu yang bersangkutan. 2). Teori Kepribadian Neo-Freud. Penganut Neo-Freud percaya bahwa hubungan sosial menjadi dasar pembentukan dan pengembangan kepribadian. Alfred Adler memandang manusia berusaha supaya dapat mencapai berbagai sasaran yang rasional yang disebutnya gaya hidup, menekankan pada usaha individu untuk mengatasi perasaan rendah diri. Harry Stack Sullivan menekankan bahwa manusia terus menerus berusaha membangun hubungan yang berarti dan bermanfaat dengan orang lain. Ia terutama tertarik padaberbagai usaha individu untuk mengurangi tekanan, seperti kegelisahan. Karen Horney memfokuskan pada pengaruh hubungan anakorang tua, dan keinginan individu untuk mengatasi perasaan gelisah. Horney mengemukakan bahwa para individu dikelompokkan ke dalam 3 golongan kepribadian sebagai berikut : (a)Individu yang patuh adalah mereka yang ingin mendekati orang lain (mereka ingin disayangi, dibutuhkan, dan diharapkan). (b) Individu yang agresif adalah mereka yang ingin menjauhi orang lain (mereka ingin mengungguli dan dikagumi). (c) Individu yang ingin lepas adalah mereka yang ingin lepas dari orang lain yang dulu berhubungan dengan dirinya (mereka menginginkan kebebasan, kepercayaan diri, mencukupi kebutuhan sendiri, dan bebas dari kewajiban). Banyak pemasar menggunakan teori NeoFreud ini secara intuitif. Misalnya jika seorang pemasar ingin memposisikan produk mereka sebagai produk yang memberikan kesempatan menjadi bagian dan dihargai orang lain dalam lingkungan kelompok/sosial tertentu, maka pemposisian produk tersebut berdasarkan pengggambaran karakterisitik individu yang yang patuh menurut Horney. 3)Teori sifat merupakan awal penting berpisahnya dari pengukuran kualitatif yang menjadi ciri khas gerakan pengikut Freud dan Neo-Freud. Orientasi Teori Sifat terutama bersifat kuantitatif /empiris. Teori ini memfokuskan pada pengukuran kepribadian menurut karakteristik psikologis khusus yang disebut sifat. Sifat didefinisikan sebagai cara yang khas dan relatif bertahan lama yang dapat membedakan seorang individu dari individu lain.Tes sifat kepribadian tunggal yang dipilih (yang hanya mengukur satu sifat) sering disusun terutama untuk dipakai dalam studi perilaku konsumen. Tes kepribadian ini mengukur berbagai sifat seperti keinovatifan konsumen (seberapa besar kemauan seseorang untuk menerima berbagai pengalaman baru), materialisme konsumen (tingkat kecenderungan konsumen pada "kepemilikan duniawi"), dan etnosentrisme konsumen (konsumen untuk menerima/menolak berbagai produk buatan luarnegeri).Para peneliti sifat telah menemukan bahwa biasanya lebih realistis mengharapkan kepribadian berhubungan dengan cara konsumen membuat pilihan mereka atas konsumsi golongan produk yang luas, bukan atas merk tertentu.

\section{Keputusan Konsumen}

Kotler (2005: 42) mengemukakan bahwa pengambilan keputusan merupakan suatu kegiatan individu yang secara langsung 
terlibat mendapatkan dan mempergunakan barang yang ditawarkan. Kotler (2017:235) sebelum memutuskan untuk melakukan pembelian barang atau jasa, konsumen biasanya akan melalui 5 tahapan yaitu : (1) Pengenalan masalah. Proses pembelian dimulai ketika pembeli mengenal suatu masalah atau kebutuhan. Pengenalan kebutuhan ini ditujukan untuk mengetahui adanya kebutuhan dan keinginan yang belum terpenuhi dan terpuaskan. (2) Pencarian informasi. Seseorang yang tergerak oleh stimulus akan berusaha mencari lebih banyak informasi yang terlibat dalam pencarian akan kebutuhan. (3) Evaluasi alternative merupakan proses di mana suatu alternative pilihan disesuaikan dan dipilih untuk memenuhi kebutuhan konsumen. Bagaimana konsumen mengevaluasi alternative barang yang akan dibeli tergantung pada masingmasing individu dan situasi membeli spesifik. (4) Keputusan membeli merupakan proses dalam pembelian yang nyata. Jadi, setelah tahap di atas dilakukan, maka konsumen harus mengambil keputusan apakah membeli atau tidak. (5) Perilaku setelah pembelian. Tugas pemasar tidak berakhir saat produk dibeli, melainkan berlanjut hingga periode pasca pembelian. Setelah pembelian produk terjadi, konsumen akan mengalami suatu tingkat kepuasan atau ketidakpuasan.

\section{Kerangka Konseptual dan Pengembangan Hipotesis}

Variabel penelitian ini terdiri dari tiga jenis variabel yaitu variabel dependen yang berupaspsial dan kepribadian. Variabel independen dalam penelitian ini keputusan mahasiswa. Berikut hubungan antar variabelpenelitian.

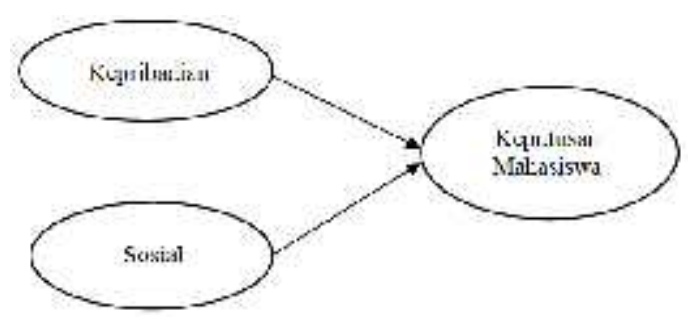

Gambar 1. Kerangka Konseptual Sumber: Peneliti 2019

\section{Pengaruh kepribadian Terhadap} KeputusanMahasiswa

Perilaku seseorang dalam membeli sesuatu juga dipengaruhi oleh faktor-faktor kepribadian konsumen yang bersangkutan. Faktor pribadi menggabungkan antara tatanan psikologis dan pengaruh lingkungan. Termasuk watak, dasar seseorang, terutama karakteristik dominan mereka. Meskipun kepribadian adalah salah satu konsep yang berguna dalam mempelajari perilaku konsumen, beberapa pemasar percaya bahwa kepribadian mempengaruhi jenis-jenis dan merek-merek produk yang dibeli. Kepribadian seseorang terbentuk disebabkan oleh bermacam-macam indikator, seperti pekerjaan orang tua, keadaan ekonomi dan gaya hidup. Semakin tinggi jabatan orang tua dalam bekerja, mapan dari segi ekonomi dan gaya hidup yang semakin meningkat, maka semakin tinggi keputusannya untuk membeli suatu produk.

PenelitianDarmawati (2007), Mariaji dan Yuniati (2014), Iskandar (2015), mengungkapkan bahwa faktor pribadi berpengaruh signifikan terhadap keputusan konsumen. Sedangkan penelitian, Nouraie, Moorineh, Kordi (2014), Sitohang (2013), mengungkapkan bahwa faktor pribadi berpengaruh tidak signifikan terhadap keputusan konsumen. 
Berdasarkan dari hasil kajian teori, hasil penelitian terdahulu, dan logika berfikir maka dirumuskan hipotesis sebagai berikut : $\mathrm{H}_{1}$ : Kepribadian berpengaruh signifikan terhadap keputusan mahasiswa dalam memilih Prodi Manajemen pada PTS di Surabaya.

\section{Pengaruh Sosial Terhadap Keputusan Mahasiswa}

Setiap manusia dalam kehidupan sehari-harinya selalu bersosialisasi atau berhubungan dengan orang lain. Baik secara langsung maupun tidak langsung. Interaksi yang terjadi secara terus menerus dapat mempengaruhi perilaku pembeliannnya. Tingkah laku konsumen dipengaruhi oleh faktor-faktor sosial seperti kelompok referensi, keluarga, serta peran dan status sosial konsumen. Kelompok referensi memiliki pengaruh langsung (tatap muka) atau pengaruh tidak langsung pada sikap dan perilaku seseorang. Kelas sosial kadangkadang berupa suatu sistem kasta dimana anggota dari kasta yang berbeda untuk peranan-peranan tertentu dapat mengubah keanggotaan kasta mereka, termasuk dalam pembelian suatu produk. Faktor sosial dapat dilihat dari hubungan dengan teman, keluarga dan orang tua dalam mempengaruhi keputusan pembelian. Semakin tinggi hubungan dengan teman, keluarga dan orang tua, maka semakin tinggi keputusan konsumen untuk melakukan pembelian. Penelitian yang dilakukan oleh Mariaji dan Yuniati (2014), Haqueet al. (2010), mengungkapkan bahwa faktor sosial berpengaruh signifikan terhadap keputusan konsumen. Sedangkan penelitian Darmawati (2007), Sitohang (2013), Iskandar (2015), Setiawanta (2013) mengungkapkan bahwa faktor sosial berpengaruh tidak signifikan terhadap keputusan konsumen.
Berdasarkan dari hasil kajian teori, hasil penelitian terdahulu, dan logika berfikir maka dirumuskan hipotesis sebagai berikut : $\mathrm{H}_{2}$ :Sosial berpengaruh secara parsial terhadap keputusan mahasiswa dalam memilih Prodi Manajemen pada PTS di Surabaya.

\section{METODE PENELITIAN}

Penelitian ini merupakan penelitian explanatory yaitu penelitian yang menjelaskan hubungan kausalitas antara beberapa variabel melalui pengujian hipotesis. Dimana hubungan tersebut bisa melalui hubungan korelasi atau saling berhubngan, untuk mengetahuisumbangan dari variabel satu ke variabel lainnya.Dalam penelitian ini menjelaskan pengaruh antara variabel sosial dan kepribadian terhadap keputusan mahasiswa. Populasi dalam penelitian ini adalah mahasiswa S1 angkatan 2017 program studi manajemen pada beberapa PTS di Surabaya dengan jumlah 949 mahasiswa. Sampel diambil sejumlah 281mahasiswa dengan menggunakan rumus Slovin. Adapun pengambilan sampel ditentukan dengan accidental sampling. Teknik pengambilan data dalam penelitian ini dilakukan melalui penyebaran kuesioner dan skala pengukuran kuesioner penelitian ini menggunakan skala likert.

\section{Operasionalisasi dan Pengukuran Variabel}

Variabel-variabel yang digunakan dalam penelitian ini: Variabel terikat adalah Keputusan mahasiswa (Y) dan Variabel Bebas $(\mathrm{X})$, yang terdiri dari : 1. Sosial $\left(\mathrm{X}_{1}\right)$. 2.Kepribadian $\left(\mathrm{X}_{2}\right)$.

\section{Sosial}

Sekelompok orang seperti teman, keluarga, dan status sosial mahasiswa di masyarakat, mempengaruhi mahasiswa dalam memilih program studi manajemen. 
Faktor sosial diukur melalui indikator keberadaan teman yaitu adanya teman yang dapat mempengaruhi mahasiswa dalam memilih program studi manajemen, keberadaan keluarga, adalah adanya orang tua atau saudara yang dapat mempengaruhi mahasiswa dalam memilih program studi manajemen, status sosial di masyarakat adalah kedudukan sosial mahasiswa dalam suatu kelompok di masyarakat.

\section{Kepribadian}

Kepribadianadalah sifat dan pola kebiasaan yang dimiliki mahasiswa, yang dipengaruhi oleh lingkungan terdekatnya, untuk memilihprogram studi manajemen kemudian diekspresikan dalam suatu tindakan yaitu memutuskan program studi manajemen yang dipilihnya.Faktor kepribadian diukur melalui indikator pekerjaan orang tua adalah kegiatan orang tua mahasiswa untuk memenuhi kebutuhan hidupnya. Gaya hidup adalah pola kebiasaaan mahasiswa dalam menjalani kehidupan sehari - hari.Keadaan ekonomi adalah kemampuan mahasiswa untuk membiayai kuliahnya.

\section{Keputusan Mahasiswa}

Proses mahasiswa untuk menilai kemudian memilih dari berbagai alternatif program studi, sesuai dengan kepentingannya dengan menetapkan suatu pilihan terhadap program studi manajemen tertentu yang dianggap paling baik.Faktorkeputusan mahasiswa diukur indikator pengenalan kebutuhan adalah pengidentifikasian kebutuhan dan keinginan dari seorang mahasiswa yang belum terpenuhi dari program studi manajemen. Pencarian informasi adalah pengumpulan berbagai informasi seorang mahasiwa tentang program studi manajemen untuk memenuhi kebutuhannya. Evaluasi alternatif adalah proses menilai dari beberapa alternatif program studi yang sesuai dengan kebutuhan seorang mahasiswa.Memutuskan adalah proses seorang mahasiswa dalam pemilihan program studi manajemen yang nyata. Perilaku setelah memutuskan adalah adanya rasa puas atau tidak puas dari seorang mahasiswa setelah memutuskan memilih program studi manajemen.

\section{Teknik Analisis Data}

Tahapan analisis dalam penelitian ini adalah:

1. Uji Validitas dan Reliabilitas

a. Uji Validitas

Validitas adalah suatu derajat ketepatan alat ukur penelitian tentang isi sebenarnya yang diukur. Analisis bertujuan menguji apakah tiap butir pertanyaan sahih. Menurut Sugiyono (2016:134) menyatakan bahwa bila koefisien korelasi sama dengan 0.3 atau lebih (paling kecil 0,3), maka butir instrumen dinyatakan valid.

b. Uji Reliabilitas

Instrumen yang reliabel adalah instrumen yang bila digunakan beberapa kali untuk mengukur objek yang sama, akan menghasilkan data yang sama. Reliabilitas variabel ditentukan berdasarkan nilai alpha cronbach, apabila nilai alpha lebih besar dari 0,6 maka dikatakan variabel tersebut reliabel atau dapat diandalkan. Untuk mempermudah analisis digunakan aplikasi pengolah data SPSS.

2. Uji Asumsi Klasik

3. Analisis Regresi Linier Berganda

Analisis regresi linier berganda digunakan untuk mengukur ada atau tidaknya pengaruh antara faktor Sosial $\left(\mathrm{X}_{1}\right)$, Kepribadian $\left(\mathrm{X}_{2}\right)$, sebagai variabel 
independent (bebas) terhadap keputusan mahasiswa (Y) sebagai variabel dependent (terikat).

Adapun persamaan regresi adalah sebagai berikut :

$$
\mathrm{Y}=\mathrm{a}+\mathrm{b}_{1} \mathrm{X}_{1}+\mathrm{b}_{2} \mathrm{X}_{2}+\mathrm{e}
$$

Dimana :

$$
\begin{array}{ll}
\mathrm{Y} & =\text { Keputusan mahasiswa } \\
\mathrm{X}_{.1} & =\text { Sosial } \\
\mathrm{X}_{.2} & =\text { Kepribadian } \\
\mathrm{a} & =\text { Konstanta } \\
\mathrm{bi} & =\text { Koefisien regresi } \\
\mathrm{e} & =\text { Variabel penyangga }
\end{array}
$$

4. Koefisien Determinasi Berganda $\left(\mathrm{R}^{2}\right)$

5. Pengujian Hipotesis

a. Pengujian pengaruh simultan dengan Uji F

Uji F dilakukan untuk menguji signifikansi pengaruh simultan antaraSosial $\left(\mathrm{X}_{1}\right)$, Kepribadian $\left(\mathrm{X}_{2}\right)$, terhadap keputusan mahasiswa (Y) dengan derajat kesalahan $5 \%$.

b. Pengujian pengaruh parsial dengan Uji $\mathrm{t}$

Uji t dilakukan untuk menguji signifikansi pengaruh parsial antara Sosial $\left(\mathrm{X}_{1}\right)$, Kepribadian $\left(\mathrm{X}_{2}\right)$, terhadap keputusan mahasiswa (Y).

\section{HASIL PENELITIAN DAN PEMBAHASAN}

\section{Hasil penelitian}

\section{Uji Validitas}

Uji validitas dilakukan untuk menguji hasil sebaran kuesioner kepada responden yang menyatakan layak atau valid atas item-item pernyataan yang disusun sebagai indikator-indikator variabel

\begin{tabular}{|c|c|c|c|}
\hline \multirow{7}{*}{ Sosial $\left(\mathrm{X}_{1}\right)$} & & S1g & \\
\hline & $X_{1 \cdot 1}$ & 0,600 & Valid \\
\hline & $X_{1 \cdot 2}$ & 0,615 & Valid \\
\hline & $X_{1 \cdot 3}$ & 0,717 & Valid \\
\hline & $\mathrm{X}_{1.4}$ & 0.751 & Valid \\
\hline & $\mathrm{X}_{1.5}$ & 0,654 & Valid \\
\hline & $\mathrm{X}_{1.6}$ & 0,651 & Valid \\
\hline \multirow{9}{*}{$\begin{array}{c}\text { Kepribadian } \\
\left(\mathrm{X}_{2}\right)\end{array}$} & $\mathrm{X}_{2.1}$ & 0,581 & Valid \\
\hline & $\mathrm{X}_{2.2}$ & 0,694 & Valid \\
\hline & $\mathrm{X}_{2.3}$ & 0,747 & Valid \\
\hline & $\mathrm{X}_{2.4}$ & 0,703 & Valid \\
\hline & $\mathrm{X}_{2.5}$ & 0,704 & Valid \\
\hline & $\mathrm{X}_{2.6}$ & 0,605 & Valid \\
\hline & $\mathrm{Y}_{.1}$ & 0,519 & Valid \\
\hline & $\mathrm{Y}_{2}$ & 0,627 & Valid \\
\hline & $\mathrm{Y}_{3}$ & 0,727 & Valid \\
\hline \multirow{7}{*}{$\begin{array}{c}\text { Keputusan } \\
\text { Mahasiswa } \\
\text { (Y) }\end{array}$} & $\mathrm{Y}_{4}$ & 0,552 & Valid \\
\hline & $Y_{5}$ & 0,465 & Valid \\
\hline & $Y_{6}$ & 0,540 & Valid \\
\hline & $\mathrm{Y}_{7}$ & 0,662 & Valid \\
\hline & $\mathrm{Y}_{8}$ & 0,568 & Valid \\
\hline & $\mathrm{Y}_{9}$ & 0,502 & Valid \\
\hline & $\mathrm{Y}_{10}$ & 0,491 & Valid \\
\hline
\end{tabular}
penelitian. Berikut hasil pengujian validitas dengan perhitungan koefisien korelasi Pearson Product Moment :
Tabel 1. Uji Validitas

Koef

Variabel Pernyataan korelasi Kesimpulan

Sumber : Olahan data peneliti 2019

Berdasarkan tabel 1 di atas menunjukkan bahwa hasil pengujian validitas indikator dari semua variabel bebas maupun variabel terikat menunjukkan valid, karenakoefisien korelasi (rhitung) $\geq 0,3$ antara skor item dan skor total.

\section{Uji Reliabilitas}




\begin{tabular}{|c|c|c|c|}
\hline $\begin{array}{l}\qquad \mathrm{Uji} \\
\text { mengetahui } \\
\text { instrumen } \quad(k \\
\text { Berikut hasil } \mathrm{p} \\
\mathrm{Ta}\end{array}$ & $\begin{array}{l}\text { liabilitas } \\
\text { ceandalan } \\
\text { uesioner) } \\
\text { engujian Re } \\
\text { el 2. Uji Re }\end{array}$ & $\begin{array}{l}\text { diguna } \\
\text { atau } \\
\text { yang } \\
\text { liabilit } \\
\text { iabilitas }\end{array}$ & $\begin{array}{l}\text { kan untuk } \\
\text { konsistensi } \\
\text { digunakan. } \\
\text { s: }\end{array}$ \\
\hline Variabel & $\begin{array}{c}\text { Cronbach } \\
\text { Alpha }\end{array}$ & $\begin{array}{l}\text { Nilai } \\
\text { Kritis }\end{array}$ & Kesimpulan \\
\hline & & 0.6 & \\
\hline epribadian $\left(\mathrm{X}_{2}\right)$ & 0,753 & 0.6 & Reliabel \\
\hline $\begin{array}{c}\text { Keputusan } \\
\text { Mahasiswa (Y) }\end{array}$ & 0,753 & 0.6 & Reliabel \\
\hline
\end{tabular}

Sumber : Olahan data peneliti 2019

Berdasarkan tabel 2 dapat diketahui

bahwa variabel-variabel tersebut telah reliabel, karena semua nilai alpha > 0.6. Hal ini berarti bahwa semua daftar pertanyaan dari masing-masing variabel adalah reliabel. Dengan demikian maka daftar pertanyaan seluruh variabel adalah reliabel untuk mengukur masing-masing variabel.

\section{Pengujian Asumsi Klasik}

\section{a. Uji multikolinieritas}

Multikolinier adalah adanya hubungan linier antara variabel bebas. Adanya multikolinier dapat dilakukan dengan melihat Variance Inflation Factor (VIF). Apabila VIF $<10$, maka tidak terjadi multikolinieritas.

Tabel 3. Uji multikolinieritas

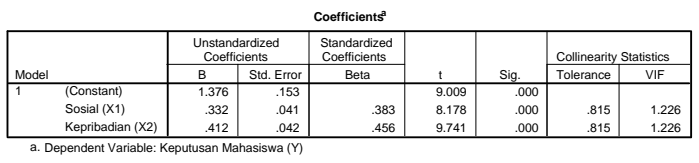

Dari tabel 3 tampak bahwa nilai VIF dibawah 10, maka dapat dikatakan tidak terjadi multikolinieritas.

\section{b.Uji Heterokedastisitas}

Heterokedastisitas artinya variasi variabel tidak sama untuk semua pengamatan. Cara menegetahui gejala Heterokedastisitas yaitu dengan menggunakan metode grafik. Jika tidak ada pola tertentu (bergelombang, melebar, kemudian menyempit) serta titik-titik menyebar di atas dan di bawah angka 0 pada sumbu Y maka tidak terjadi Heterokedastisitas.Berikut adalah Heterokedastisitas dengan grafik scatterplot

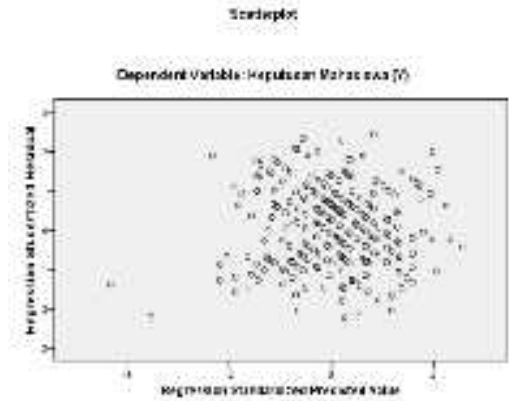

Gambar 2. Uji Heterokedastisitas

Sumber : Olahan data peneliti 2019

Dari gambar di atas diketahui titik menyebar secara acak baik di atas maupun di bawah angka nol pada sumbu Y, tidak ada pola yang jelas.Maka tidak terjadi Heterokedastisitas.

\section{Analisi Regresi Linier Berganda}

Analisis dalam penelitian ini menggunakan variabel bebas $(\mathrm{X})$ yang terdiri dari dua variabel bebas antara lain, variabel $\mathrm{X}_{1}$ (Sosial), $\mathrm{X}_{2}$ (Kepribadian), sedangkan varibel terikatnya (Y) adalah Keputusan Mahasiswa. Mengetahui seberapa besar pengaruh variabel bebasvariabel $\mathrm{X}_{1}$ (Sosial), $\mathrm{X}_{2}$ (Kepribadian), terhadap varibel terikatnya $\mathrm{Y}($ Keputusan Mahasiswa)maka dapat dihitung dengan menggunakan teknik analisis regresi linear berganda. Berdasarkan hasil perhitungan dari model regresi linear berganda diperoleh hasil persamaan regresi yang dapat dilihat dalam tabel 4 dibawah iniTabel 4. Hasil Perhitungan Regresi Linear Berganda

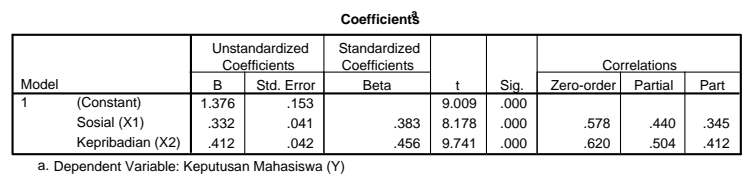

Sumber : Olahan data peneliti 2019 
Dari tabel 4 dapat diketahui bahwa persamaan regresi yang dihasilkan adalah sebagai berikut :

$\mathrm{Y}=\mathrm{a}+\mathrm{b}_{1} \cdot \mathrm{X}_{1}+\mathrm{b}_{2} \cdot \mathrm{X}_{2}+\mathrm{e}$

$Y=1,376+0,332 X_{1}+0,412 X_{2}$

Keterangan :

$\mathrm{Y} \quad=$ Keputusan Mahasiswa

A $\quad=$ Intersep/konstan

$\mathrm{b}_{1}-\mathrm{b} 2=$ Koefisien masing-masing variabel

$\mathrm{X}_{1} \quad=$ Sosial

$\mathrm{X}_{2}=$ Kepribadian

e $\quad=$ Komponen/Standart eror

Hasil uji dari Coeffiens, dapat disimpulkan sebagai berikut :

1. Nilai variabel dependen (Y) Keputusan Mahasiswadapat dilihat dari nilai konstantanya sebesar 1,376, dengan catatan jika variabel independen yang terdiri dari bebas variabel $\mathrm{X}_{1}$ ( Sosial ), $\mathrm{X}_{2}$ (Kepribadian), bernilai konstan (tetap), maka diperoleh nilai Keputusan

Mahasiswa sebesar 1,376satuan.

2. Nilai $b_{1}$ sebesar 0,332

Menunjukkan jika nilaikepribadian tetap sedangkan Sosial $\left(\mathrm{X}_{1}\right)$ meningkat $1 \%$, maka akan dapat meningkatkan Keputusan Mahasiswa (Y) sebesar 0,332 satuan. Koefisien bernilai positif artinya terjadi hubungan positif antara $\operatorname{Sosial}\left(\mathrm{X}_{1}\right)$ denganKeputusan Mahasiswa.Semakin bertambah nilai dari Sosial $\left(\mathrm{X}_{1}\right)$ semakin naik Keputusan Mahasiswa (Y).

3. Nilai $b_{2}$ sebesar 0,412

Menunjukkan jika nilai sosial tetap sedangkan Kepribadian $\left(\mathrm{X}_{2}\right)$ meningkat $1 \%$, maka akan dapat meningkatkan Keputusan Mahasiswa (Y) sebesar 0,412satuan. Koefisien bernilai positif artinya terjadi hubungan positif antara Kepribadian $\left(\mathrm{X}_{2}\right)$ dengan Keputusan Mahasiswa.Semakin bertambah nilai dariKepribadian $\left(\mathrm{X}_{2}\right)$ semakin naik Keputusan Mahasiswa (Y).

\section{Uji Koefisien Determinasi $\left(\mathbf{R}^{\mathbf{2}}\right)$}

Pengujian koefisien determinasi $\left(\mathrm{R}^{2}\right)$ digunakan untuk mengukur proporsi atau persentase kemampuan model dalam menerangkan variabel terikat. Koefisien determinasi berkisar antara nol sampai satu $\left(0 \leq \mathrm{R}^{2} \geq 1\right)$. Jika $\mathrm{R}^{2}$ semakin besar (mendekati satu), maka dapat dikatakan bahwa pengaruh variabel bebas (X) adalah besar terhadap variabel terikat (Y). Hal ini berarti model yang digunakan semakin kuat untuk menerangkan pengaruh variabel bebas terhadap variabel terikat dan demikian sebaliknya.

Tabel 5. Hasil Koefisien Determinasi Model Summary

\begin{tabular}{ccccc}
\hline Model & R & RSquare & $\begin{array}{c}\text { Adjusted } \\
\text { RSquare }\end{array}$ & $\begin{array}{c}\text { Std. } \\
\text { Error of } \\
\text { the } \\
\text { Estimate }\end{array}$ \\
\hline 1 & $.710^{\mathrm{a}}$ & .504 & .500 & .26923
\end{tabular}

a. Predictors: (Constant), Kepribadian (X2), Sosial (X1)

Sumber : Olahan data peneliti 2019

Berdasarkan tabel 5 dapat dilihat bahwa: $\mathrm{R}$ Square sebesar 0,504 berarti variabel Keputusan Mahasiswa dapat dipengaruhi oleh variabel Sosial, Kepribadian, sebesar $50,4 \%$. Sedangkan sisanya $49,6 \%$ dapat dipengaruhi oleh variabel-variabel lain yang tidak diteliti oleh penelitian ini.

\section{Uji Simultan (Uji F)}

Pengujian ini dilakukan untuk melihat apakah semua variabel bebas yang dimasukkan dalam model mempunyai pengaruh secara bersama-sama terhadap variabel terikat.Tabel 6 berikut ini adalah uji F : 


\begin{tabular}{cccccc}
\hline \multicolumn{6}{c}{ Tabel 6. Hasil Uji FAnova } \\
\hline Model & $\begin{array}{c}\text { Sum } \\
\text { of } \\
\text { square }\end{array}$ & of & $\begin{array}{c}\text { Mean } \\
\text { Square }\end{array}$ & F & Sig \\
\hline 1 & & & & & \\
\hline Regression & 20.464 & 2 & 10.222 & 141.161 & .000 \\
Residul & 20.151 & 278 & 072 & & \\
Total & 40.614 & 280 & & & \\
\hline
\end{tabular}

a. Predictors (Constant, Kepribadian (X2), Sosial (X1)

b. Dependent Variable, Keputusan Mahasiswa (Y)

Sumber : Olahan data peneliti 2019

Pada tabel 6 dapat diketahui bahwa nilai $\mathrm{F}_{\text {hitung }}=141,161$ dengan tingkat signifikansi $=0,000<0,05$ sehingga menolak Ho dan menerima Ha. Berdasarkan kriteria pengujian hipotesis jika tingkat signifikansinya $<0.05$, menunjukkan bahwa variabel independent yaitu Sosial dan Kepribadian secara bersama-sama mempengaruhi Keputusan Mahasiswa.

\section{Uji Parsial (Uji t)}

Pengujian ini dilakukan untuk mengetahui seberapa jauh pengaruh suatu variabel independent secara parsial (individual) terhadap variabel dependent. Berikut ini hasil output uji t :

Tabel 7. Hasil Uji t

Hasil dari tabel 7 adalah sebagai berikut :

1. Variabel Sosial $\left(\mathrm{X}_{1}\right)$ dengan $\alpha=$ 0,041.Karena nilai $\alpha<0,05$ maka dapat ditarik kesimpulan bahwa variabel Sosial secara parsial berpengaruh terhadap Keputusan Mahasiswa.

2. Variabel Kepribadian $\left(\mathrm{X}_{2}\right)$ dengan $\alpha=$ 0,042 .Karena nilai $\alpha<0,05$ maka dapat ditarik kesimpulan bahwa variabel Sosial secara parsial berpengaruh terhadap Keputusan Mahasiswa.

3. Bahwa nilai $\mathrm{t}$ hitung tertinggi diantara variabel independen adalah variabel kepribadian, yaitu 9,741. Dan semua probabilitas pada variabel independent signifikan pada tingkat 5\% dan yang berada pada signifikansi terendah adalah variabel psikologis, yaitu $\alpha=0,000$. Bahwa diantara variabel independent yaitu Sosialdan Kepribadian, maka variabelyang paling dominan adalah variabel Kepribadian. Hal tersebut ditunjukkan dengan tingkat signifikan paling rendah dan koefisien yang paling besar.

\section{Pembahasan}

Dalam penelitian ini melalui regresi linear berganda didapatkan :

\section{Coefficients} $\mathrm{Y}=1,376+0,332 \mathrm{X}_{1}+0,412 \mathrm{X}_{2}$

\begin{tabular}{|c|c|c|c|c|c|c|c|c|}
\hline \multirow[b]{2}{*}{ Model } & \multicolumn{2}{|c|}{$\begin{array}{c}\text { Unstandard } \\
\text { zad }\end{array}$} & $\begin{array}{c}\text { Stan } \\
\text { d }\end{array}$ & \multirow[b]{2}{*}{$\mathbf{t}$} & \multirow[b]{2}{*}{ sig } & \multicolumn{3}{|c|}{ Correlation } \\
\hline & B & $\begin{array}{c}\text { Std. } \\
\text { Err } \\
\text { or }\end{array}$ & Beta & & & $\begin{array}{c}\text { Zero } \\
\text { orde } \\
\mathbf{r}\end{array}$ & $\begin{array}{c}\text { Parti } \\
\text { al }\end{array}$ & Part $i$ \\
\hline 1 & & & & & & & & \\
\hline Constant & 1.37 & .153 & .383 & 9.00 & .000 & .578 & .440 & $.345^{1}$ \\
\hline Sosial & .332 & .041 & .456 & 8.17 & .000 & .620 & .504 & $.412 \mathrm{j}$ \\
\hline $\begin{array}{l}\text { Kepribad } \\
\text { ian }\end{array}$ & .412 & .042 & & 9.74 & .000 & & & \\
\hline
\end{tabular}

Konstanta bernilai positif artinya menunjukkan pengaruh positif variabel rt independent. Jika variabel independent naik satu satuan, maka variabel dependen akan ${ }_{345}$ naik atau terpenuhi. Nilai semua koefisien 2 juga bernilai positif yang artinya terjadi hubungan positif antara variabel independent dan variabel dependent.

a. Dependent Variable, Keputusan Mahasiswa (Y)

Sumber : Olahan data peneliti 2019
$\mathrm{R}$ Square sebesar 0,504 berarti variabel Keputusan Mahasiswa dapat dipengaruhi oleh variabel Sosial, Kepribadian, sebesar 50,4\%. Sedangkan sisanya 49,6 \% dapat dipengaruhi oleh 
variabel-variabel lain yang tidak diteliti oleh penelitian ini.

Pengujian secara simultan menunjukkan bahwa variabel independent yaitu Sosial dan Kepribadian, secara bersama-sama berpengaruh terhadap Keputusan Mahasiswa. Hal tersebut ditunjukkan dengan $F$ Hitung sebesar 141,161 .

Dari pengujian variabel penelitian secara parsial menunjukkan bahwa variabel independent, yaitu Sosial dan Kepribadian, berpengaruh terhadap variabel dependen yaitu Keputusan Mahasiswa.

Diantara variabel independent yaitu Sosial dan Kepribadian, variabel yang paling dominan adalah variabel kepribadian. Hal tersebut ditunjukkan koefisien yang paling besar yaitu nilai $t$ hitung sebesar 9,741.

Variabel Sosial $\left(\mathrm{X}_{1}\right)$ diketahui nilai signifikansinya sebesar 0,00 . Hasil penelitian ini mendukung dari hasil penelitian sebelumnya yang dilakukan oleh Mariaji dan Yuniati (2014). Hasil penelitiannya menyatakan bahwa sosial mempunyai pengaruh yang signifikan terhadap keputusan konsumen. Hasil ini tidak mendukung hasil penelitian sebelumnya yang dilakukan oleh Sitohang (2013) yang mengungkapkan bahwa faktor sosial berpengaruh tidak signifikan terhadap keputusan konsumen.

Variabel Kepribadian $\left(\mathrm{X}_{2}\right)$ diketahui nilai signifikansinya sebesar 0,00 . Hasil penelitian ini mendukung dari hasil penelitian sebelumnya yang dilakukan oleh Mariaji dan Yuniati (2014). Hasil penelitiannya menyatakan bahwa kepribadian mempunyai pengaruh yang signifikan terhadap keputusan konsumen. Hasil ini tidak mendukung hasil penelitian sebelumnya yang dilakukan oleh Sitohang
(2013) yang mengungkapkan bahwa faktor kepribadian berpengaruh tidak signifikan terhadap keputusan konsumen

\section{Simpulan}

Berdasarkan hasil analisis dapat disimpulkan sebagai berikut :

1. Diketahui rumus regresi adalah $\mathbf{Y}=$

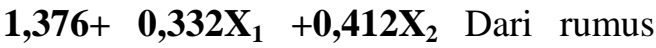
tersebutdiketahui nilai konstanta bernilai positif artinya menunjukkan pengaruh positif variabel independentyaitu Sosial $\left(\mathrm{X}_{1}\right)$ dan Kepibadian $\left(\mathrm{X}_{2}\right)$.Pada rumus tersebut menunjukkan semua koefisien bernilai positif yang artinya terjadi hubungan positif antara variabel independent dan variabeldependent.

2. Koefisiensi $\mathrm{R}$ Square sebesar 0,504 berarti variabel Keputusan Mahasiswa dapat dipengaruhi oleh variabel Sosial, Kepribadian, sebesar 50,4\%. Sedangkan sisanya 49,6\% dapat dipengaruhi oleh variabel-variabel lain yang tidak diteliti oleh penelitian ini.

3. Pengujian secara simultan menunjukkan bahwa variabel independent yaitu Sosial dan Kepribadian secara bersama-sama berpengaruh terhadap Keputusan Mahasiswa. Hal tersebut ditunjukkan dengan F Hitung sebesar 141,161.

4. Dari pengujian variabel penelitian secara parsial menunjukkan bahwa variabel independent, yaitu Sosial dan Kepribadian berpengaruh terhadap variabel dependen yaitu Keputusan Mahasiswa.

5. Diantara variabel independent, Sosial dan Kepribadian, yang paling dominan adalah variabel Kepribadian .Hal tersebut ditunjukkan dengan koefisien yang paling besar yaitu nilai t hitung sebesar 9,741. 


\section{DAFTAR PUSTAKA}

Anoraga, P. 2005. Manajemen Bisnis. Cetakan Ketiga. Rineka Cipta Jakarta.

Barkhi,R dan L.Wallace.2007.The impact of personality type on purchasing decisions in virtual stores.Inf Technol Manage 8:313-330.

Bilson, S. 2004. Panduan Riset Perilaku Konsumen. PT Gramedia Pustaka Utama. Jakarta.

Engel, J.F., R.D. Blackwel, dan P.W.Miniard. 2005. Consumer Behavior. Edisi kesepuluh. Jilid1. Binarupa Aksara. Jakarta.

Fatihudin, D., \& Mochklas, M. 2017. Analysis of Factors Affecting Consumer Decisions Buy Motorcycle (Study on City of Surabaya Indonesia).International Journal Of Innovative Research \& Development, 6(6): 107-118

Firmansyah, M.A., \& Mochklas, M. 2018. Analisa Strategi Produk, Harga, Promosi Dan Tempat Terhadap Kepuasan Pelanggan Warung Giras Di Surabaya. Jurnal EKSEKUTIF, 15(1): 281- 295

Indrawati, A. 2014. Faktor-Faktor yang Dipertimbangkan Mahasiswa Dalam Memilih Lembaga Pendidikan dan Latihan Bisnis di Kota Malang. Jurnal Kompilek 6 (1) : 53-67

Kotler, P, dan G. Amstrong. 2001.Prinsiples of Marketing. Ninth Edition.Prentice Hall,Inc.New Jersey. Terjemahan A.Sindoro.2004.Dasar-Dasar Pemasaran.Edisi 9.PT Indeks. Jakarta

Koesoemaningsih, R. 2013. Pengaruh Budaya, Sosial, Pribadi dan PsikologiTerhadap Keputusan Mahasiswa DalamMemilih Pendidikan Pada Prodi Manajemen Fakultas Ekonomi Universitas Soerjo Ngawi. Media Soerjo 13( 2): 105 - 125

Kotler, P. 2005. Manajemen Pemasaran. Edisi kesembilan belas.Jilid-2.Indeks. Jakarta

Lamb, Charles W. (2001). Pemasaran. Edisi Pertama. Salemba Empat. Jakarta

Mulyati,Y, Mailinarti, dan Masruri. 2016. Analisis Faktor-Faktor Yang Mempengaruhi Keputusan Mahasiswa
Dalam Memilih Perguruan Tinggi Swasta Di Kota Padang. Jurnal Ekonomi \& Bisnis Dharma Andalas, 18(1): 45-65

Mochklas, M., Panggayudi, D.S dan Soenarto. 2019. The Work Culture Of South Korean Companies in Indonesia. Humanities \& Social Sciences Reviews, 7(4):603-608

Mowen, J.C. dan M. Minor. 2001. Perilaku Konsumen. edisi 5. Jilid 2.Erlangga.

Jakarta.

Erlangga. Jakarta

1995. Consumer behavior.

International Edition. Prentice Hall, Inc, Englewood Cliffs. New Jersey

Mcknight, D.H., V. Choudury., \& C. J. Kacmar. 2002. Developing And Validating Trust Measure for E-Commerce: $A n$ Integrative Typology. Informatin System Research. 13(3): 334-359.

Mariajie W dan T. Yuniati. 2014. Pengaruh Perilaku Konsumen Terhadap Keputusan Pembelian Compact Disc (CD) di Surabaya. Jurnal Ilmu \& Riset Manajemen, 3(8) : 1-15

Mochklas, M., \& Setiawan, T. 2018. Sistem Informasi Manajemen. Surabaya: TS Publisher.

Mukarromah, S., Maro'ah, S., \& Mochklas, M. 2018. Implementasi Strategi Bauran Pemasaran Dalam Meningkatkan Volume Penjualan Toko Baju Senam Grosir.Com. Jurnal EKSEKUTIF, 15(2): 316-333

Purwanti, E. 2015. Analisis Faktor-Faktor Pengambilan Keputusan Mahasiswa Memilih STIE “AMA” Salatiga. Jurnal Among Makarti, 8 (16)

Setiadi, N. J. 2003. Prilaku Konsumen : Konsep dan Implikasinya untuk Strategi dan Penelitian Pemasaran. Edisi Pertama. Cetakan Pertama. Prenada Media. Jakarta.

Sumarwan, U. 2004. Perilaku Konsumen : Teori dan Penerapannya dalam Pemasaran.Cetakan Kedua. Ghalia Indonesia. Bogor. 


\section{Balance: Economic, Business, Management, and Accounting J ournal}

Vol. XVII No. 1 | B ulan J anuari Tahun 2020

Suryani, W dan P.Ginting. 2013. Faktor-Faktor yang Mempengaruhi Keputusan Mahasiswa Memilih Fakultas Ekonomi Universitas Islam Sumatra Utara Al Munawaroh Medan. Jurnal Modernisasi $9(1)$

Swastha, B dan H. Handoko. 2000. Manajemen Pemasaran : Analisa Perilaku Konsumen. Edisi I. BPFE Yogyakarta.

Sutisna, 2003. Perilaku Konsumen \& Komunikasi Pemasaran. Cetakan Kedua. Remaja Rosdakarya. Bandung.
Sugiyono. 2007. Metodologi penelitian Bisnis. Alfabeta . Bandung.

Sitohang, U. 2013. Pengaruh Budaya, Sosial, Pribadi, dan Psikologis Terhadap Keputusan Pengambilan Kredit di PT Bank Tabungan Pensiunan Nasional, TBK. Tesis. Program Studi Magister Manajemen Program Pascasarjana Universitas Atma Jaya. Yogyakarta. 
Balance: Economic, Business, Management, and Accounting J ournal Vol. XVII No. 1 | Bulan J anuari Tahun 2020 